\title{
Influence Factors and Path of the Development of Coal Enterprise- Ili Kazak Autonomous in Xinjiang As an Example
}

\author{
Cao Feng ${ }^{1, \text { a }}$ \\ ${ }^{1}$ Postdoc research center in theoretical economics, \\ Xinjiang University, Urumqi 830046,China \\ acaofeng@126.com
}

Keywords: Coal enterprise, factor, path

Abstract. Our country has abundant coal resources and is the world's most consumption and production country of coal. Since the reform and opening up, China's coal industry has rapid developed. Coal industry has constantly updated equipment; develop its core technology competence, greatly promoted the economic development of our country. However, with the change of international situation, the development of coal industry in China encountered unprecedented resistance. Some small coal enterprises are unable to cope with market fluctuations and have to close the companies; the economic benefit of large-scale coal enterprise is declining with great difficulty to develop. With the exhaustion of the natural resources, the coal enterprises should actively transformation, plan for the development of the enterprise in the new situation.

\section{The developing condition and plan of the coal market}

\subsection{The developing condition}

With dwindling of our country's coal resources and the increasingly serious environmental pollution, after the Eighteenth meeting, our country put forward the construction of ecological civilization in the primary stage of socialist construction, vigorously regulation of environmental pollution and ecological problems, such as natural resource and ect. Coal, as important natural resource in China, becomes a primary goal of rectification. Recently, the development of coal industry in China is not optimistic, appearing the phenomenon of excess production capacity, economic benefit of the major national coal is declining, and even some enterprises gain no benefit, coal industry is now faced with new market situation.

The implementation of the national policy on industry to some extent plays an important role on the development of industry. Some coal industries in our country have a demand to start introducing transmission equipment, use natural gas from fossil energy instead of coal resources, and our country advocates for coal import and restriction to export. A large amoun of coal is imported to the market, making our coal market supply quite larger than demand.

The price of coal is a big factor to influence the economic benefit of coal enterprises directly. China's coal industry appears the phenomenon of excess production capacity, coal enterprise do not follow the market rules of the exploitation of coal without restraint under the advanced production technology, causing a large number of coal accumulation, cannot cash, make enterprise losses. The coal enterprise capacity problem will affect the development of the 
enterprise, being the fact that the domestic coal supply makes the price of coal continued to fall. Balance of coal supply and demand will eventually produce a price, before that, some high mining cost of coal enterprises will expand losses, is going to decline gradually.

\subsection{The plan for development}

In response to the changes of market, we should pay attention to do the two contents. Firstly, to improve the production technology level of mine, streamlined and efficient, reduce the cost. Secondly, in the current situation of coal industry, we should accurately grasp the national related policy and focus on the enterprise development in the future.

First of all, material control to reduce cost.

(1) To quantify the indexes; setting up business inspection leading group, adhering to the business analysis meeting held every month, each quarter at management review meeting. (2) To strengthen the material planning and purchasing management; change the original material inside price into the market price, plan material consumption quantity monthly by the functional department according to the district team plan tasks and material consumption quota. (3) The salesman and keeper package team; insisted that the purchasing department salesman and keeper joint package system, guide the district team to carry out the independent, praise or punish along with material section area team. (4) Adhering to recovering old, reusing bad and recycling; mine makes the content of the recovering, reusing and recycling things, and improves cash reward ratio according to the material value, a step-wise reward $10 \%, 15 \%, 20 \%$. Strengthen material recovery and reuse of supporting materials with a certain task such as mechanical and electrical and transportation, according to the monthly production; manage the full life cycle equipment accessories and instruments for each team. (5) Complete the design of roadway and mining area optimization. On the premise of security, face gateway uses the anchor net supporting when more than a third; double support add shed from such as new support mode; system optimization design which reduces the labor efficiency and let the material input is decreased obviously.

Second is to balance manufacturing and selling, making production according to sales. (1) Reasonable planning production and penetration. With continuous decline of coal price and sales is a problem, most coal enterprises are even cannot to make ends meet, the more coal they sell, be more loss they get. (2) Arrange the production task from the management effect. Ore analyses the production task from the aspect of management requiring determining the specific production task. Under the premise of achieving the target with the minimum cost, mine can achieve profit and can guarantee the worker's normal wage.

Third is to improve the quality of coal quality promotion. (1) To strengthen coal quality management. Coal quality is not ideal, aiming at this situation, main is responsible for geological condition, the raw coal develops the good way to control coal quality by adhering to source control, process control, clear responsibility, require coal pillar robbing group along the bottom stopping, the nuggets by excavating coal floor. (2) The reasonable organization of mining. Mining should according to the actual circumstance of three coal mining face and make reasonable organization and adjusting of mining. (3) To improve sales and service. Sales work is an important part of mining management. Although we don't have to gain the initiative in sales, we still want to actively expand the market using network resources that can be made use of to establish a fixed customer relations and cooperation for enterprises. The prominent problem of competition between coal enterprises is the coal market competition, which puts 
forward higher request for coal sellers that we have to let go of the past high-profile, awake to realize the transition of the market, to take the good faith to won customer's trust, sincere attitude, proactive, expand market share.

\section{The problems in the coal development in Ili Kazak Autonomous}

The coal industry development models in Ili region at present are three main categories: the coal for social life, industrial coal and for export (domestic Xinxiang, neighboring countries). Development of coal industry in Ili region can be divided into four stages:

First stage: small mines. Its characteristics: rural collective ownership mining; individual belongs to the local state; basic using artificial, ox cart and people in the original way without any environment and safety assessment.

The second stage: water flow period. Its performance characteristics: mainly by the township collective enterprises as the main body in the business, less state-owned enterprises but larger scale, no private business. Management is not standard, mining way behind.

The third stage: improve in an all-round way. Its characteristics: all aspects of standardization, institutionalization.

The fourth stage: in large group. Features: two big coal groups in Ili putting a good stage for the development of coal.

Good condition of coal resources, slow industry development. In theory, with the implementation of western development, and construction of energy-hungry projects continue to promote a batch of coal chemical industry causing a great demand for coal, Ili coal market should have a good development potential, but seen from the data for nearly 10 years of Ili provided by local government, development of Ili coal enterprise is slow, production base is lower, the growth rate is slow. The whole industrial structure in Ili kazak autonomous is not reasonable, industrial process still belongs to the early stage. Compared with a national average, the industrial structure in Ili is quite unreasonable: the industrial proportion is too small. In 2004, the national, eastern and western proportion of industry respectively is 53\%, $52.9 \%$ and $44.4 \%$, while the proportion of Ili is only $31.8 \%$. Being an advantaged resource, the coal industry just makes a quite small contribution to the economy development in Ili region. Coal production growth is far lower than industrial developing speed, the coal industry contributed no more than $4 \%$ without giving full play to the advantage industry.

\section{The coal enterprises develop low-carbon economy}

Production process of coal enterprise is restrained by many factors such as natural geological conditions, equipment, technical level and quality of employees. To extensive mining coal and unclean usage of the high carbon energy, enterprise has many problems in extensive growth mode for a long time. Developing low carbon economy is an important way to change the coal high consumption, high emission, high pollution growth pattern of enterprise. Coal enterprises must walk on the way of low carbon production, green production, green transformation and clean use mode to realize the change of the pattern of economic development,.

"Low carbon economy" is a kind of economic model with low energy consumption, low pollution and low emission, is a major progress for human society after the agriculture civilization and industrial civilization. The essence of low carbon economy is energy efficient utilization, clean energy development, the pursuit of green GDP, the core is energy technology 
and emission reduction technology innovation, the industrial structure and institutional innovation and fundamental change of human survival and development concept. Characteristics and essence of coal enterprise itself determine its important position in promoting low-carbon economy, energy conservation and emission reductio.

\subsection{Environmental problems of coal exploitation}

Mine solid wastes; mining waste rock need large storage sites, which leads to a large number of land occupancy and serious destruction of surface vegetation. Waste contains acid, alkali, toxic, radioactive or heavy metal components piled up in open spaces in a long time will extremely be easy to oxidase decomposition, make these toxic and harmful substances pollution of soil, water and air, directly endanger human body health, affect the order of industrial and agricultural production.

Mining wastewater; mine production process of mine water are the main waste water, waste rock field leaching water and mine waste water pool, etc. Mine wastewater contains a large number of heavy metal ions, acid and alkali, suspended solids, and all kinds of the mineral processing reagents after contaminated wastewater directly or indirectly pollute the surface water, groundwater and farmland and cause serious damage to human health and the survival of other animals and plants.

Mining waste gas; mining produces a large number of dust and toxic substances; the use of explosives, diesel engine equipment and produce toxic or harmful gases and ect.

Under the condition of sustainable development to deal with climate change: leading to insufficient official aid brings to the coal enterprise the problems of fund and the technical difficulties making the clean coal enterprises development faced with severe test.

\subsection{Energy conservation and emissions reduction technologies}

Cleaner production technology is used for no waste or less waste production technology, to realize zero discharge and manufacture green products through this technology, and the technology occupies a core position in the system. To achieve less investment, high output, low pollution, emissions of pollutants, enterprises need to eliminate the pollution outside the environment in the process of production including waste emissions reduction technology, reducing surface subsidence and ecological reconstruction integration technology, the coalbed methane development technology, underground coal gasification technology and etc.

Pollution control technology is used to eliminate pollutants through the construction of waste purification device to achieve the purification of poisonous and harmful waste. Enterprises should actively promote the soot desulfurization technology for the control of air pollution, water pollution prevention and control technology, such as landfill and incineration, solid waste treatment technologies.

\subsection{The solutions to develop low carbon economy}

(1) Perfect the policy system of coal enterprises to develop low carbon economy

Make good use of the current policy and law environment, perfect the laws and regulations of coal enterprises to develop low carbon economy system, and accelerate to develop the low-carbon economic law and other special security related policies on low carbon development, actively learn from foreign low carbon economy legislation, combined with the actual situation in our country, make scientific planning. At the same time, the government should play the role of guidance, the establishment of carbon finance platform, in the service of low carbon development, set up a carbon tax system, realize paid use of coal resources, 
controlling carbon emissions, carbon trading mechanism, bring coal enterprise low carbon development intrinsic motivation.

(2) Improve technical support and innovation ability

Grasp the opportunity of low carbon emission plan to participate in exchange and communication of technology with foreign countries and the introduction of advanced low-carbon technologies, set up a technology research and development, increase the intensity of low carbon technology research and development, set up low carbon technology development system, reasonable exploitation of mine resources, increase the recovery rate of resources and coal processing.

(3) Adjustment of coal industrial structure.

To guide the coal industry structure adjustment, to speed up the coal enterprise to develop low carbon can improve the core competitiveness of coal enterprises. On the one hand, it can increase coal affiliate product through extension of the coal industry chain. On the other hand, to convert the coal energy to cleaning products and low carbon operation at the same time will step up the coal industry health and sustainable development.

(4)Bring in technical talents and the funds injection

Low carbon talent is the precondition for the coal enterprises to develop low carbon economy, money is the motive force of coal enterprise development a low carbon economy. To identify talent from internal enterprise, to invite experts and professors in the field of low carbon to train for employees; and at the same time, to create retain talented person's soft environment, optimize the talent team provide intellectual support for the development of coal enterprises.

\section{Summary}

The cycle of the coal industry chain forms a coal mining enterprise symbiosis of industry cluster. This not only makes all kinds of waste resources in the coal production process reduce the emissions, reusing and recycle, which solves the pollution control at the end of the pure passivity. It effectively improves the economic benefit of coal enterprise and environmental benefits through the cascade utilization of resources and energy. Building a resource-conserving, environment-friendly society is a basic national policy in China. The rise of low carbon economy and the development of circular economy provide a great opportunity for coal enterprises' development.

\section{References}

[1]Yu Xiongfei, The transformation research of the development of coal enterprise in china[J],Energy technology and management,2004(02):175-178.

[2]Zhang Hui, Path discussion of the development of coal enterprise in the low carbon economy[J],Business guide,2014(02):69-71.

[3 ]Yang Bo, Trade condition and development strategy of the coal industry[J], Management manager,2014(10):214-215.

[4]Liu Ke, transformation and upgrading of coal enterprise in the new area[J]Shanxi coal,2014(03):78-80.

[5]Liu Hui, The developing prosperity of coal enterprise[J],National business,2013(04):17 $-18$. 